\title{
MYANMAR
}

\section{Assessing the Impact on Household Incomes and Poverty of Declines in Remittances Due to COVID-19}

\author{
Xinshen Diao and Kristi Mahrt
}

Remittances are an important income source for the poor in Myanmar, particularly for lowincome rural households. This policy note focuses on the likely impact on household income and poverty in Myanmar of declines in international and domestic remittances caused by the COVID-19 pandemic. We used a microsimulation model to do so. Our principal findings include:

- With an assumed 50 percent drop in income from international remittances and 30 percent drop from domestic remittances, many poor households are now more impoverished. In addition, many low-income, but not poor remittance-receiving rural households are expected to fall into poverty.

- Nationwide, the poverty rate among remittance-receiving households will rise by 7.5 percentage points. More than 600,000 already poor households will become more impoverished and another 200,000 households that were not poor before the COVID-19 shock will fall into poverty. Four million people live in these more impoverished and newly impoverished households.

- Rural households account for the majority of vulnerable remittance-receiving households -88 percent of the more impoverished and newly impoverished households nationwide reside in rural communities.

- Among poor remittance-receiving rural households following the COVID-19 shock, almost 250,000 have children under 5 years of age. Falling remittance incomes for these households is likely to adversely affect the nutrition and health of these young children.

- The annual amount of financial support needed to regain the pre-shock food and nutrition security levels for poor remittance-receiving rural households following the COVID-19 shock is estimated to be 230 billion Myanmar kyat or 150 million US dollars.

\section{Background}

Myanmar has approximately 4 million international migrants, one of the highest population shares in Asia. In consequence, international remittance inflows are an important income source for many households in both rural and urban areas. International migrant workers are predominantly employed in China, Thailand, Malaysia, and India, mostly via border passage. For 2015 it was estimated that remittances sent home from legal migrants were 3.5 billion US dollars, equivalent to 5 percent of GDP (Akee and Kapur 2017). If illegal migrant remittances were included, the value of remittances 
is estimated at 8 billion US dollars and 13 percent of GDP. Many long-term domestic migrant workers also provide essential support to family members in other parts of Myanmar.

The lockdowns in China and Thailand and the closure of many factories in Thailand in February and March after the COVID-19 outbreaks resulted in workers from Myanmar in these countries losing their jobs and returning home. According to the International Organization for Migration, there were more than 60,000 returnees as of April 23 (IOM 2020). At the same time, between 80,000 and 100,000 migrants were awaiting entry at border gates, especially the Myawaddy border gate with Thailand, and a second large influx of returnees was expected (Myanmar Times, 7 May 2020). Information from recent phone interviews with remittance agents in Bangkok conducted by IFPRI shows that the most vulnerable international migrants are unskilled workers, many of whom are now without jobs and stuck in Thailand due to cross-border mobility restrictions. However, those who can return home are unlikely to find job opportunities in Myanmar due to the pandemic's depressive effects on the domestic economy.

In the meantime, the COVID-19 outbreak within Myanmar also has important impacts on domestic remittance flows. As a result of lockdown measures to contain the spread of the virus and post-lockdown restrictions on people's movement and certain economic activities, many domestic migrant workers will lose their jobs. Remittance income received by their families will fall significantly.

This policy note focuses on the impacts of declines in international and domestic remittances caused by the COVID-19 pandemic on household income and poverty in Myanmar. We developed a microsimulation model to assess such impacts. Because the most recent Myanmar Living Conditions Survey (MLCS) conducted in 2017 is not available for public use, data from the Myanmar Poverty and Living Conditions Survey (MPLCS) conducted in 2015 is used for the analysis (MoPF and World Bank 2017).

\section{Remittances are an important income source for Myanmar households}

The MPLCS data shows that nationwide about 24 percent of households have remittance incomes either from international or domestic migrant family members. ${ }^{1}$ Figure 1 displays the total number of households with remittance income and the number of households with international remittance income as a percent of total households. In addition to dividing households into rural and urban households, throughout the analysis we further subdivide rural households into farm, nonfarm, smallholder, ${ }^{2}$ landless, and female-headed households. As shown in Figure 1, a greater share of female-headed households receive remittance income than do other types of rural households.

Spatially, Chin, Shan, and Mon states have disproportionally more international remittancereceiving households than do other states and regions (CSO, UNDP, and World Bank 2020). However, the MPLCS 2015 data is representative only at the zonal level and not at the state/regional level. Chin and Shan belong to the Hills and Mountains zone and Mon belongs to the Delta zone. These two zones account for 52 percent of rural households nationwide, and 57 percent of rural households in these zones receive international remittance income. Moreover, at a national level, 68 percent of low-income rural households that receive international remittance income are in these two zones.

\footnotetext{
${ }^{1}$ According to the Central Statistical Organization, UNDP, and World Bank (2020), 19.5 percent of households in the more recent 2017 MLCS received remittance income from any source, both domestic and international - 18.5 percent among urban households and 19.9 percent among rural households.

${ }^{2}$ We define smallholders as those who own or cultivate farmland less than 5 acres.
} 
Figure 1. Households receiving any remittances and receiving international remittances by household group, percent of households

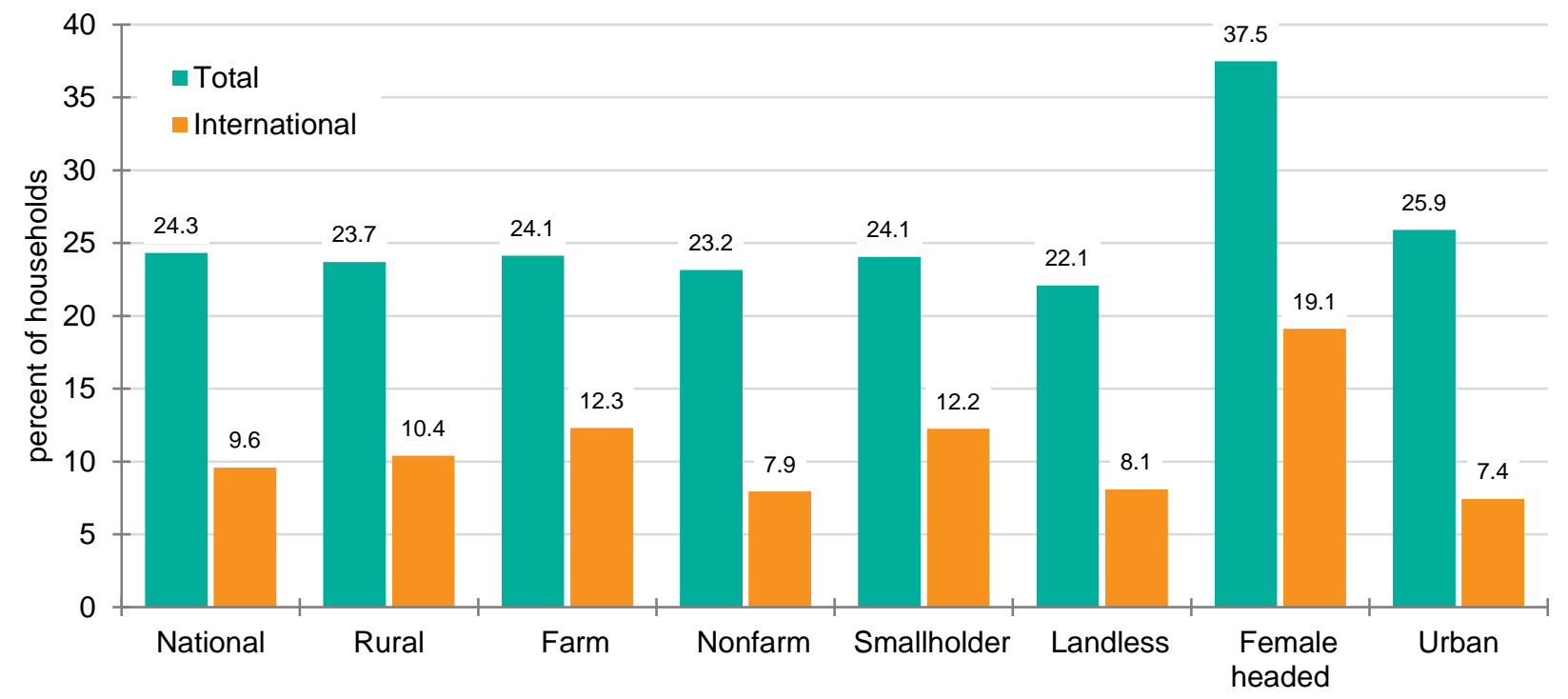

Source: Authors' calculation using data from MPLCS 2015.

Note: In this and following figures, rural households are sub-classified into five categories: farm, nonfarm, smallholder, landless, and female-headed, while urban households are only grouped into one category.

Our analysis focuses on households that receive remittance income and that are poor or lowincome. We define low-income households as those in the second lowest expenditure quintile (Q2) but are not classified as poor prior to the remittance shock. Table 1 show the share of poor and lowincome remittance-receiving households in each household group. In Table 1, we separate households that receive only international remittances from households that receive any remittances (domestic or international). The poverty prevalence rate is higher among rural remittance-receivers than among urban remittance-receivers. Out of the 600,000 poor remittance-receiving households nationwide, 530,000 are rural households. Among these rural households, smallholders, nonfarm, and landless household groups have the highest poverty rates. Among these remittance-receiving poor rural households, 37 percent have children under 5 years old.

Table 1. Poor and low-income households among remittance-receiving households by household group, percent of households

\begin{tabular}{lcccc} 
& $\begin{array}{c}\text { Households receiving } \\
\text { any remittances } \\
\text { Poor }\end{array}$ & \multicolumn{2}{c}{$\begin{array}{c}\text { Households receiving } \\
\text { international remittances }\end{array}$} \\
\hline National & 22.9 & 12.1 & 19.8 & 14.8 \\
\hline Rural & 28.5 & 14.3 & 23.8 & 17.0 \\
Farm & 27.1 & 15.0 & 25.7 & 18.7 \\
Nonfarm & 30.4 & 13.4 & 20.0 & 13.6 \\
Smallholder & 30.9 & 14.4 & 30.1 & 16.4 \\
Landless & 29.3 & 14.9 & 21.2 & 16.2 \\
Female-headed & 24.2 & 12.8 & 20.7 & 14.3 \\
\hline Urban & 9.4 & 6.6 & 5.2 & 6.4 \\
\hline
\end{tabular}

Source: Authors' calculation using data from MPLCS 2015.

Note: Low-income households are those belong to the second lowest expenditure quintile but not poor in MPLCS 2015.

Many remittance-receiving households were not poor before the shock, even if they had low incomes. At the national level, 12.1 percent of remittance-receiving households are low-income, about 320,000 households. Again, the percentages of low-income remittance-receivers are higher for rural groups than for urban households overall - nationwide, of the 320,000 low-income remittance-receiving households, more than 260,000 reside in rural communities. Among lowincome remittance-receiving rural households, 31 percent have children under 5 years of age. 
Figure 1 and Table 1 focus on the share of various household groups that receive remittance income. However, it also is necessary to understand the importance of remittance income relative to other income sources for households. In Figure 2, income from total remittances is presented as the percentage share of total income for different types of remittance-receiving households. Figure 3 focuses on international remittance-receiving households and international remittances as a percentage share of total income for different household groups.

Figure 2. Total remittance income as a percentage share of total income for all, poor, and low-income remittance-receiving households

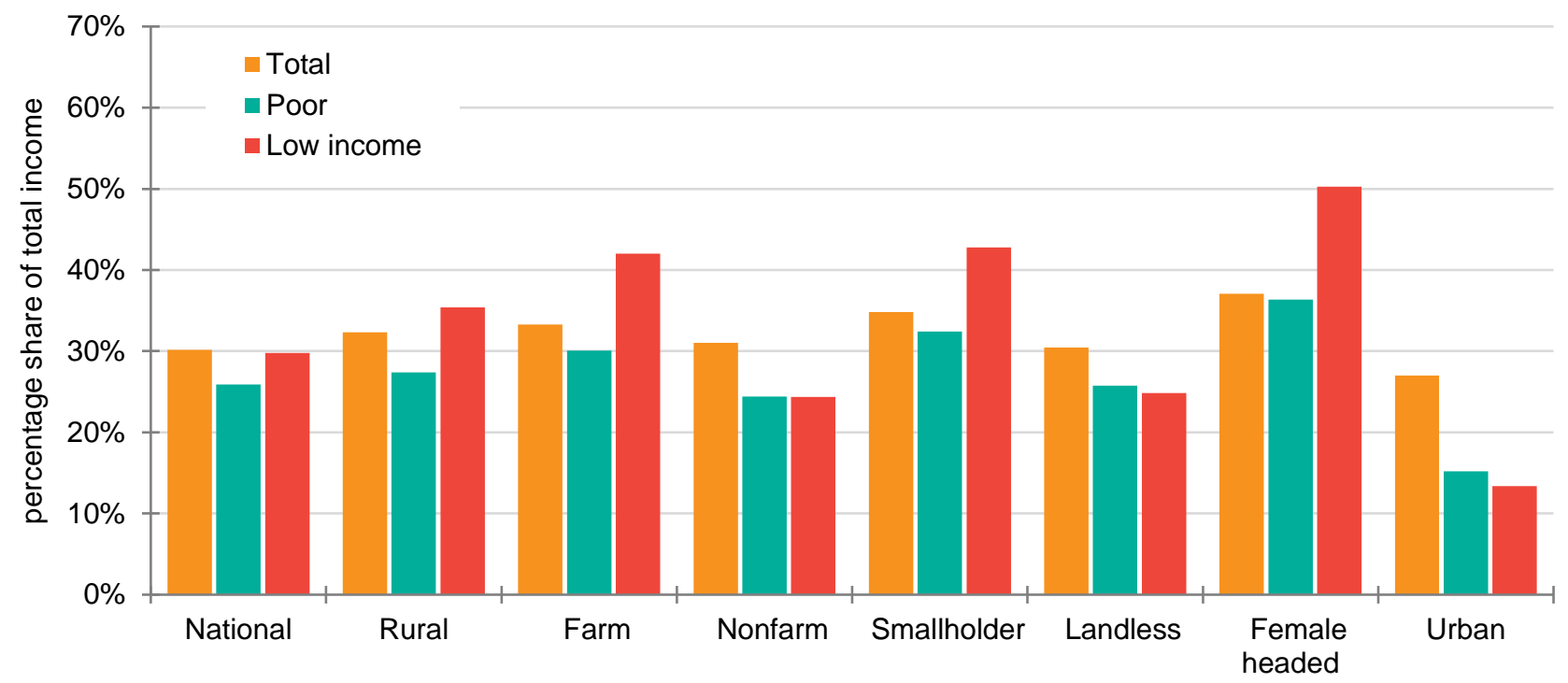

Source: Authors' calculation using data from MPLCS 2015

Note: Farm, nonfarm, smallholders, landless, and female-headed are part of rural households. Low-income households are those belong to the second lowest expenditure quintile but not poor in MPLCS 2015.

Figure 2 shows heterogeneity in the importance of remittances among different types of households and between poor and low-income households within each group. As expected, remittances are one of the most important income sources for female-headed rural households that receive remittances, contributing 37 percent of their income on average. However, between poor and low-income remittance-receiving female-headed rural household groups, the importance of remittances differs. Remittances account for 36 percent of total income for poor female-headed rural households, while the share of remittances in total income is 50 percent for low-income femaleheaded rural households. Remittances are generally more important for low-income than for poor rural households across most types of households. Thus, remittances likely keep many rural households out of poverty. ${ }^{3}$

Remittances are a particularly important income source for international remittance-receiving households (Figure 3). At the national level, international remittances account for 43 percent of total income in international remittance-receiving households. The highest shares are at 59 and 67 percent for the poor and low-income international remittance-receiving female-headed rural households, respectively.

\footnotetext{
3 There exists clear regional heterogeneity in the distribution of remittances received by households, particularly for international remittance income. Based on data from the 2017 MLSC, a World Bank report identified that in 10 out of 15 state/regions in Myanmar, households receive more international remittances than domestic remittances. For example, international remittances account for 22.5 15.4, and 14.2 percent of total household incomes in Kayin, Mon, and Chin, respectively (CSO, UNDP, and World Bank 2020). However, the 2015 MPLCS is not designed to represent households at the state/region level, which limits our ability to identify high international remittance dependent households across states/regions.
} 
Figure 3. International remittance income as a percentage share of total income for all, poor, and low-income international remittance-receiving households

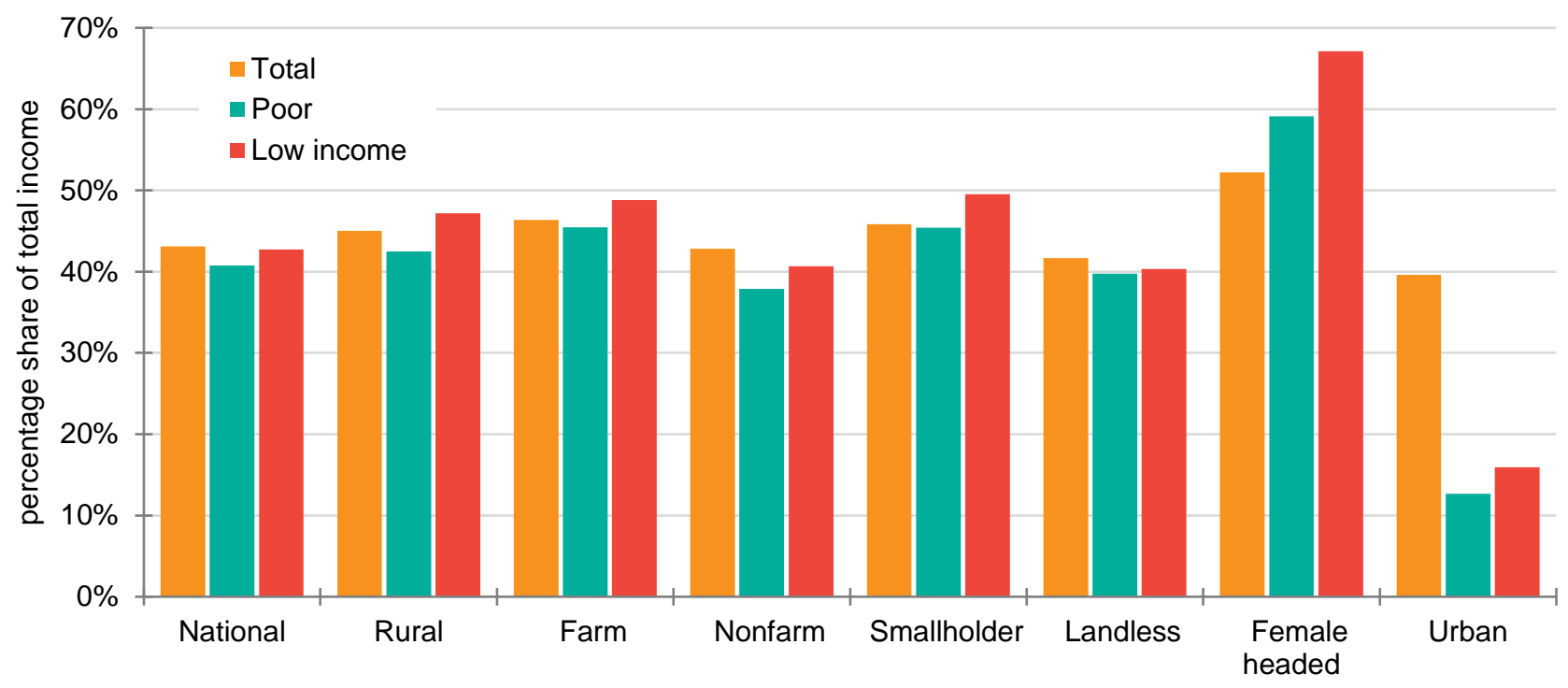

Source: Authors' calculation using data from MPLCS 2015.

Note: Farm, nonfarm, smallholders, landless and female-headed are part of rural households. Low-income households are those belong to the second lowest expenditure quintile but not poor in MPLCS 2015.

Figure 3 also shows that international remittances are important for all international remittancereceiving households and not just for poor and low-income households. However, among international remittance-receiving urban households, international remittances seem to be much more important for higher-income households than for poor and low-income households - almost 40 percent of income comes from international remittances for the international remittance-receiving urban households as a group. In contrast, the shares are only 13 and 16 percent for urban poor and low-income households, respectively.

\section{Heterogenous impacts of falling remittances on the incomes of rural households}

In the absence of actual data on COVID-19 related reductions in remittance income or numbers of returned migrants at the individual household level, we design two scenarios to assess the impact of falling remittances on rural household income and poverty.

- In the first scenario, we focus on international remittances only, which is shocked by a 50 percent decline uniformly across all international remittance-receiving households.

- In the second scenario, in addition to the 50 percent shock on international remittances, domestic remittances are shocked by a 30 percent decline uniformly across all households.

While the shocks are uniform in both scenarios, the impact of such shocks differs across households depending on the importance of remittances to individual households. Figure 4 shows the cumulative distribution of the drop in total income across all poor and low-income households that receive international remittances under the first scenario of households experiencing a 50 percent uniform shock in their international remittance income. Figure 5 is similar, showing the distribution of the drop in total income experienced by all poor and low-income households that receive any remittances under the second scenario of a 50 percent shock on international remittance shock plus a 30 percent of shock on domestic remittance income. 
Figure 4. Cumulative distribution of impact on total household income of a 50 percent drop in international remittances among international remittance-receiving poor and lowincome households

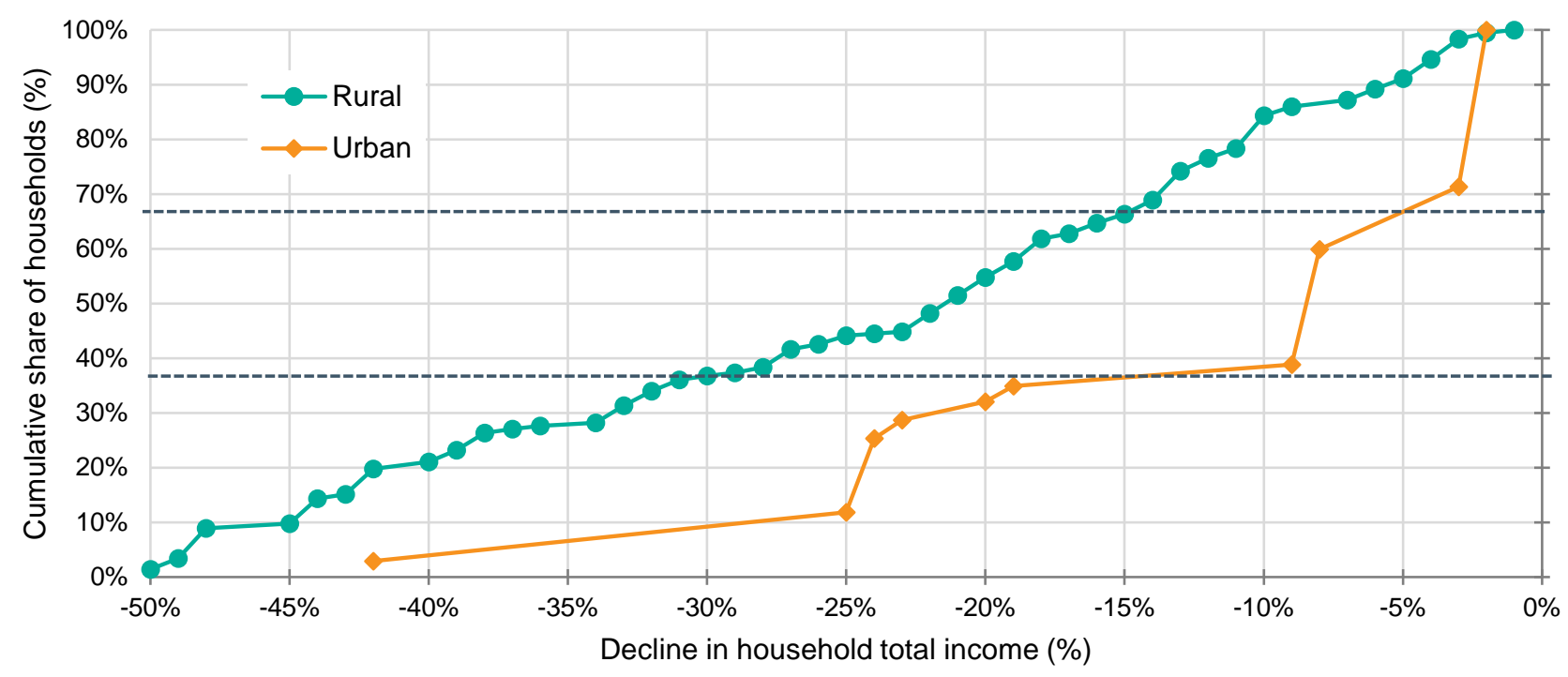

Source: Authors' calculation from Myanmar microsimulation model.

Note: Poor and low-income international remittance-receiving households only.

Figure 5. Cumulative distribution of impact on total household income of a 50 percent drop in international remittance and a 30 percent drop in domestic remittances among remittance-receiving poor and low-income households

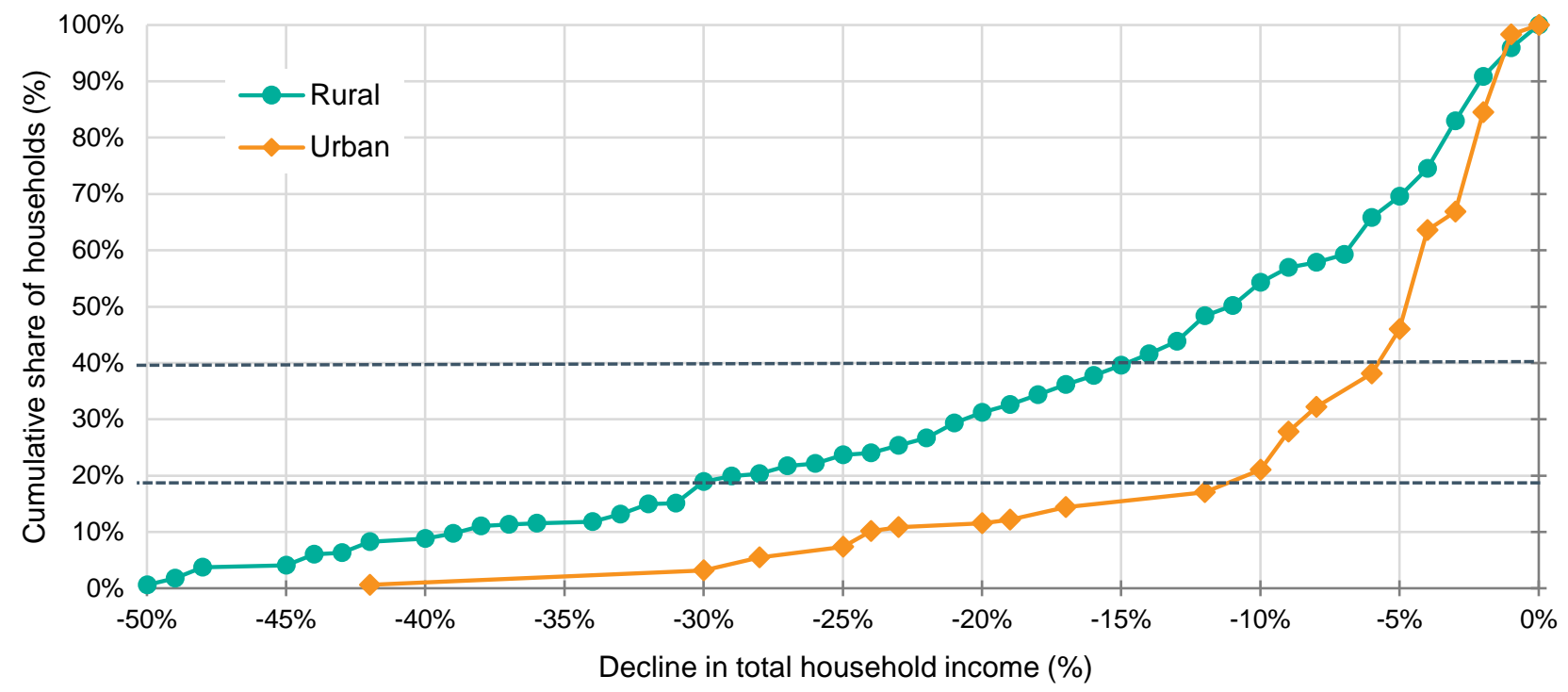

Source: Authors' calculation from Myanmar microsimulation model.

Note: Poor and low-income remittance-receiving households only.

Comparing the two figures, it is apparent that rural households receiving only international remittances lose a greater share of their total income due to COVID-19 related shocks that do rural households with both types or only domestic remittances.

The upper dashed horizontal line in both figures indicates the share of rural poor and low-income remittance-receiving households whose total income fell by at least 15 percent, while the lower dashed horizontal line indicates how many households experienced falls in total income of 30 percent or more. The 50 percent international remittance shock causes total income to fall by at least 15 percent for more than 65 percent of rural poor and low-income households with only international remittance income and by more than 30 percent for more than 35 percent of such households (Figure 4). When the 50 percent international remittance shock is combined with a 30 percent domestic 
remittance shock, almost 40 percent of poor and low-income rural households receiving any remittances experience a reduction in their total income of more than 15 percent, and for almost 20 percent of such households, the reduction in total income is more than 30 percent (Figure 5).

Figure 6. Percent declines in total income due to a 50 percent international remittance shock and a 30 percent domestic remittance shock among poor and low-income remittance-receiving households

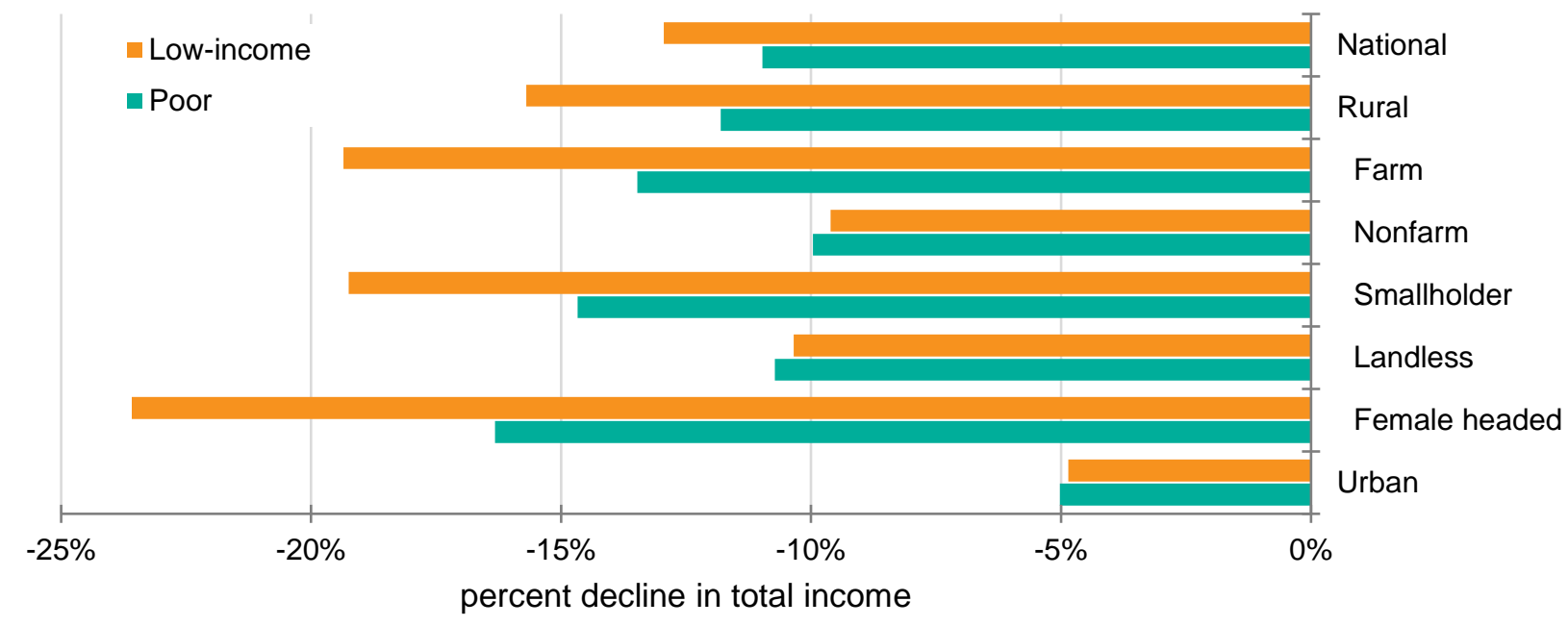

Source: Authors' calculation from Myanmar microsimulation model.

Note: Farm, nonfarm, smallholders, landless and female-headed are part of rural households. Remittance-receiving households only.

Figure 6 focuses on poor and low-income households that receive any remittance income, showing the expected fall in total income across household groups due to the 50 percent of international remittance shock and 30 percent domestic remittance shock. For rural households with remittance income, declines in total income are consistently higher among low-income households compared to poor households. In contrast, urban poor and low-income households experience a similar decline in income. While the remittance shocks might result in smaller percentage declines in income among poor rural households than among low-income rural households, the impact on poor rural households should not be underestimated because of their initial much lower income levels. Again, income falls the most among both poor and low-income female-headed rural households. Income also falls significantly among smallholders and farm households, particularly in the low-income group.

\section{Rising poverty among remittance-receiving rural households}

Because declining remittances disproportionally affects low-income rural households, many of their incomes will fall below the poverty line as a consequence of the COVID-19 remittance shock. ${ }^{4}$ Figure 7 shows the percentage of low-income remittance-receiving households that become poor after the shock.

The results displayed in Figure 7 are alarming: 65 percent of low-income remittance-receiving rural households are expected to fall into poverty after the remittance shock. The worst affected are smallholder and female-headed rural remittance-receiving households - 73 and 80 percent of lowincome households in these two groups will likely become poor after the remittance shock, respectively.

\footnotetext{
${ }^{4}$ The poverty line is defined according to household expenditure per adult equivalent. We assume that declines in expenditure are proportional to declines in incomes. Households falling into poverty are those whose per adult equivalent expenditure level falls below the poverty line.
} 
Figure 7. Low-income remittance-receiving households that become poor after 50 percent international remittance shock and 30 percent domestic remittance shock, percent share

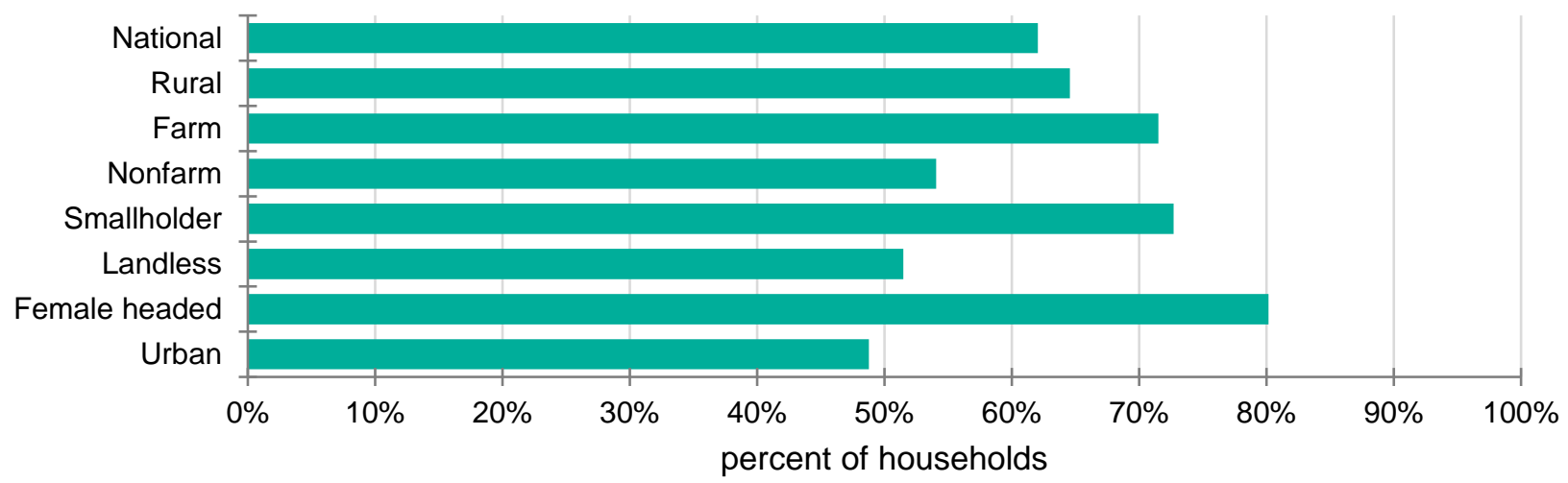

Source: Authors' calculation from Myanmar microsimulation model.

Note: Low-income households are those in the second lowest expenditure quintile but not poor (MPLCS 2015).

Farm, nonfarm, smallholders, landless, and female-headed are part of rural households. Remittance-receiving households only.

The national poverty rate for Myanmar is expected to rise because of such significant declines in income among low-income remittance-receiving households. In the poverty assessment here, we consider increased poverty coming only from previously low-income remittance-receiving households that previously were in the second expenditure quintile. However, falling remittances can also cause some households previously in richer expenditure quintiles, i.e., Q3 to Q5, to lose significant income. However, as such households are more likely to have savings and other assets to help them cope with these income shortfalls, we did not consider them in the poverty assessment.

Figure 8 shows rising household poverty across all remittance-receiving household groups. At the national level, the share of poor households will increase by 7.5 percentage points after the shock, rising to 30.4 percent. That is, in addition to the 600,000 remittance-receiving households that were already poor before the shock, 200,000 households that previously were low-income but not poor will also fall into poverty after the remittance shock. In total, 4 million people are members of these already poor and newly poor remittance-receiving households.

Figure 8. Household poverty rates among remittance-receiving household groups before and after the remittance shock

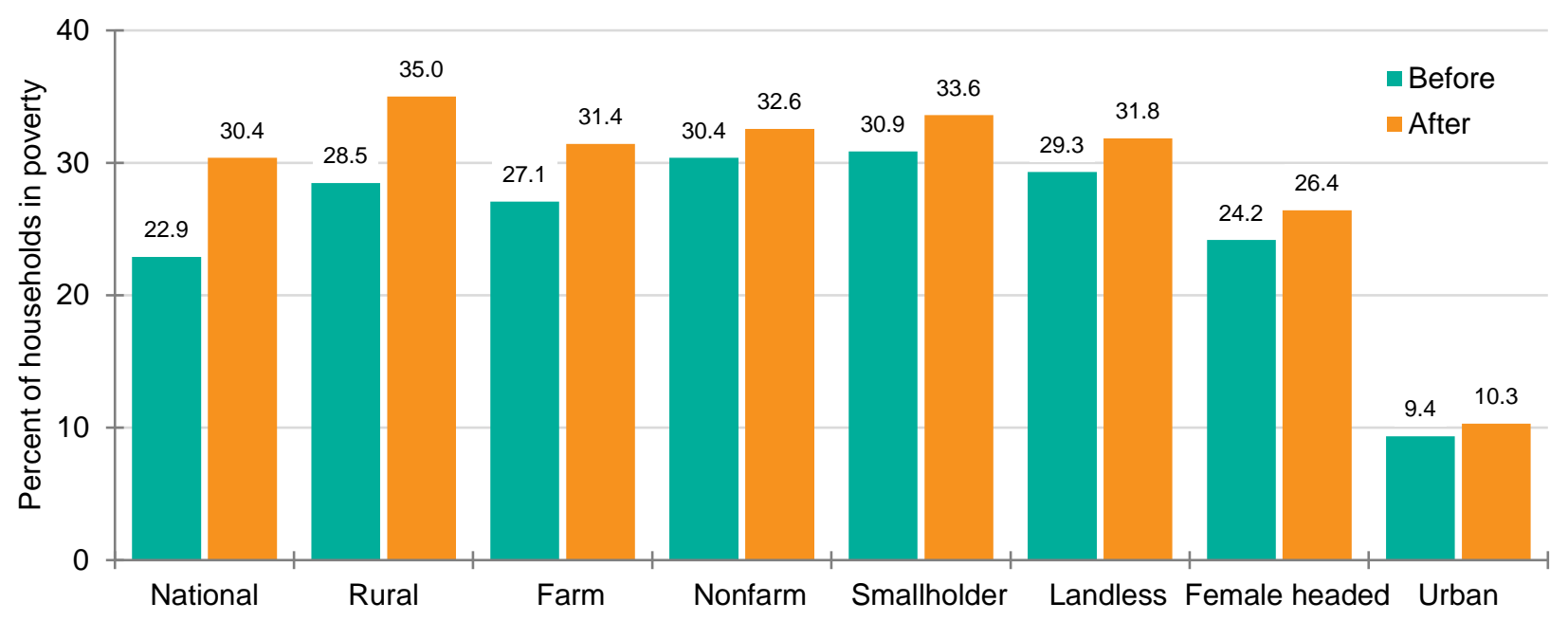

Source: Authors' calculation from Myanmar microsimulation model.

Note: Poverty rate before the shock is calculated according to the number of poor households in MPLCS 2015 . The poverty rate after the shock considers both the numbers of poor households prior to the shock and newly poor households that belong to low-income households in the second lowest expenditure quintile but not poor in MPLCS 2015.

Remittance-receiving households only. Farm, nonfarm, smallholders, landless, and female-headed are part of rural households.

The newly poor households are overwhelmingly rural, accounting for 87.4 percent of all newly poor households (Figure 9). That is, in addition to the 530,000 rural remittance-receiving households 
that were already in poverty before the shock, there are 170,000 previously low-income rural households that will become poor after the remittance shock. In total, 3.5 million rural people will become poor due to falling remittances. Nationally, among rural households, 58.3 percent of the newly poor households belong to previously low-income farm households.

Figure 9. Newly poor low-income households by type of remittance-receiving households, percent of households

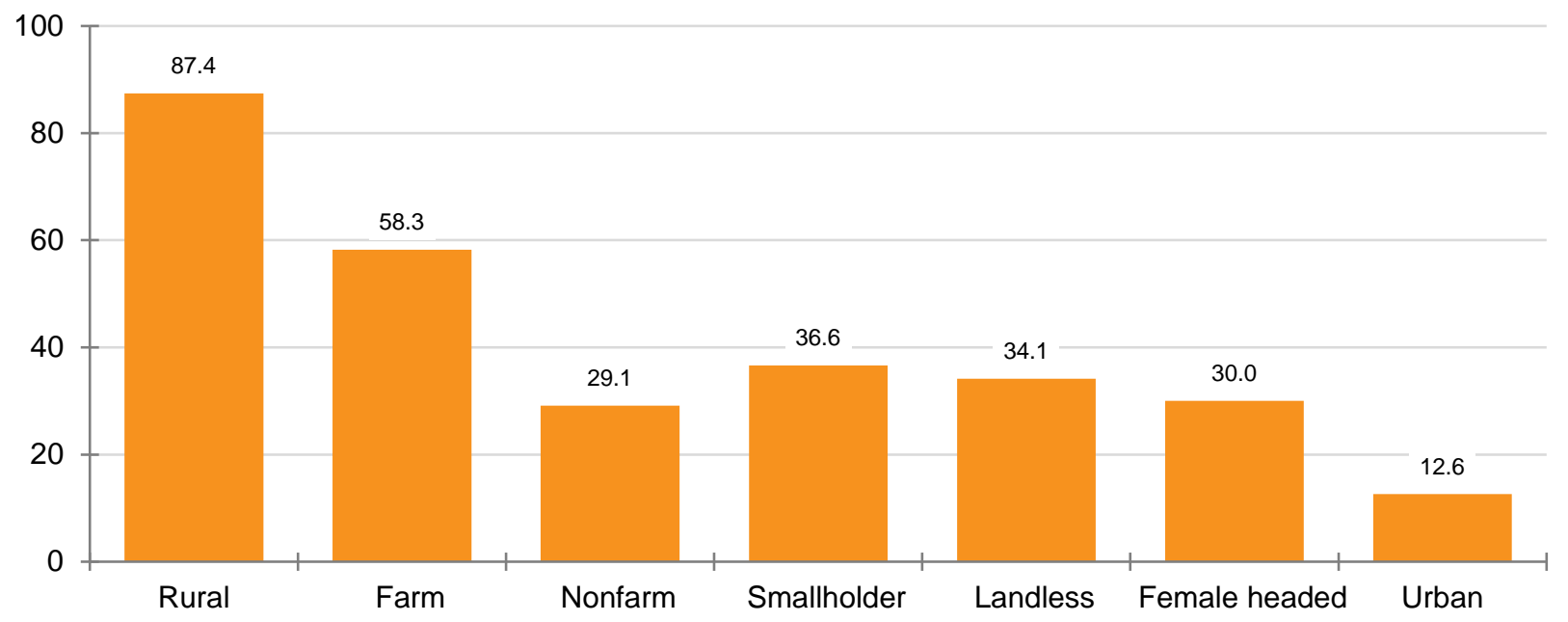

Source: Authors' calculation from Myanmar microsimulation model.

Note: Farm, nonfarm, smallholders, landless, and female-headed are part of rural households. Remittance-receiving households only.

\section{Estimated financial support required for affected remittance-receiving poor households}

The analysis shows that declining remittances due to COVID-19 related shocks lead to poor remittance-receiving households falling deeper into poverty and to many previously low-income remittance-receiving households becoming poor. We estimate the total amount of financial support required to maintain the food and nutrition security for already poor remittance-receiving households at their pre-shock level and for previously low-income remittance-receiving households to stay out of poverty (Table 2).

Table 2. Estimated financial support requirement for already poor and newly poor

remittance-receiving households

\begin{tabular}{|c|c|c|c|c|c|c|}
\hline & \multicolumn{2}{|c|}{$\begin{array}{l}\text { Lost income for } \\
\text { already poor } \\
\text { households }\end{array}$} & \multicolumn{2}{|c|}{$\begin{array}{l}\text { Lost income for low } \\
\text { income households } \\
\text { falling into poverty }\end{array}$} & \multicolumn{2}{|c|}{ Total } \\
\hline & $\begin{array}{c}\text { Kyat, } \\
\text { billions }\end{array}$ & $\begin{array}{l}\text { USD, } \\
\text { millions }\end{array}$ & $\begin{array}{c}\text { Kyat, } \\
\text { billions }\end{array}$ & $\begin{array}{l}\text { USD, } \\
\text { millions }\end{array}$ & $\begin{array}{c}\text { Kyat, } \\
\text { billions }\end{array}$ & $\begin{array}{l}\text { USD, } \\
\text { millions }\end{array}$ \\
\hline National & 144 & 95 & 89 & 59 & 233 & 154 \\
\hline Rural & 136 & 90 & 84 & 56 & 221 & 145 \\
\hline Farm & 81 & 54 & 60 & 39 & 141 & 93 \\
\hline Nonfarm & 55 & 36 & 25 & 16 & 80 & 52 \\
\hline Smallholder & 56 & 37 & 31 & 21 & 88 & 58 \\
\hline Landless & 62 & 41 & 31 & 20 & 93 & 61 \\
\hline Female-headed & 44 & 29 & 30 & 20 & 74 & 49 \\
\hline Urban & 8 & 5 & 4 & 3 & 12 & 8 \\
\hline
\end{tabular}

Source: Authors' calculation from Myanmar microsimulation model.

Note: Adjusted to 2019 prices.

- For already poor households, the required financial support is based on lost remittance income, which totals about 144 billion Myanmar kyat or 95 million US dollars annually. 
- For the previously low-income but not poor remittance-receiving households, we estimate the required financial support according to the difference between the poverty line and their adjusted expenditure levels after losing remittance income. A total of 89 billion Myanmar kyat or 59 million US dollars per year would assist in preventing low-income households from falling into poverty.

\section{Concluding remarks}

Remittances are an important income source for many households in Myanmar, particularly for smallholder and rural female-headed households. Remittances are especially important to enable many low-income rural households to stay out of poverty. Therefore, declining remittance income resulting from the COVID-19 outbreak can have significant poverty effects. The study finds:

- Declines in remittance income affect remittance-receiving households heterogeneously. With a 50 percent decline in international remittance income and a 30 percent decline in domestic remittance income, many poor households that lost remittances are now even more impoverished and many low-income remittance-receiving rural households are expected to fall into poverty.

- Nationwide, the poverty rate among remittance-receiving households will rise by 7.5 percentage points. More than 600,000 already poor households will become more impoverished and another 200,000 households that were not poor before the shock will fall into poverty. In total, 4 million people are members of these more impoverished and newly poor households.

- Rural households account for most of the vulnerable remittance-receiving households - 88 percent of already poor and newly poor households nationwide. 700,000 rural households and 3.5 million household members are either more impoverished or will become poor as a result of lost remittances due to the COVID-19 outbreak.

- There are about 200,000 poor remittance-receiving rural households with young children under 5 years old and another 45,000 low-income rural households with young children falling into poverty after the shock. Falling remittance incomes for such households likely will have negative effects on the nutrition and health of these young children.

- Based on the 50 percent decline in international remittances and the 30 percent decline in domestic remittances analyzed in this policy note, an estimated 230 billion Myanmar kyat or 150 million US dollars per year is the total amount of financial support needed to maintain the pre-shock food and nutrition security of existing poor remittance-receiving households and to prevent previously non-poor but low-income remittance-receiving households from falling into poverty.

Unlike other COVID-19 shocks associated with domestic lockdown measures, of which many are possibly temporary in nature, the decline in remittances caused by COVID-19 is likely to be prolonged for a year or more. Though some returned migrants may eventually find local jobs, incomes from their new local jobs are unlikely to be comparable to their previous earnings from migrant work. Therefore, the negative income and poverty effects of COVID-19 on poor and lowincome remittance-receiving households are likely to persist. Moreover, taking into consideration the linkage effects caused by reduced demand of remittance-receiving households for agricultural and nonagricultural products and services that other households and firms provide, the economywide negative impact of COVID-19 will be even larger than the adverse income effects estimated here (Diao et al. 2020).

The Government of Myanmar recently released a comprehensive and sensible economic relief plan (MOPFI 2020). The Myanmar COVID-19 Economic Relief Plan (CERP) includes unconditional cash and in-kind transfers to the most vulnerable and affected households (CERP, 4.1.2 (d)). This 
policy note could be helpful in identifying the most vulnerable and affected households among remittance-receiving households and in determining the amount of financial support they need. The CERP also emphasizes cash or lending support to farmers, small agri-processors, and agri-businesses (CERP, 2.1.7 (b) and (d)). As the analysis from a recent IFPRI-Myanmar SSP Policy Note shows, the largest immediate impact of COVID-19 on farmers and agri-business people will be on the ability of households to pay for inputs, hired labor, and other costs. Falling remittance incomes will degrade the food and nutrition security of rural households as well as their ability to farm productively (Boughton et al. 2020). Therefore, financial support to affected poor and low-income remittance-receiving rural households is an important and necessary mechanism to support Myanmar's agricultural sector and to enable it to quickly recover from COVID-19 related shocks.

\section{References}

Akee, R. and D. Kapur. 2017. Myanmar Remittances. Final Report, S-53405-MYA-1. Washington DC: International Growth Center.

Boughton, D., J. Goeb, I. Lambrecht, D. Mather, and D. Headey. 2020. Strengthening Smallholder Agriculture is Essential to Defend Food and Nutrition Security and Rural Livelihoods in Myanmar against the COVID 19 Threat, Elements for a Proactive Response. Myanmar Strategy Support Program Policy Note 02. Yangon: International Food Policy Research Institute.

CSO (Central Statistical Organization), UNDP (United Nations Development Programme), and World Bank. 2020. Myanmar Living Conditions Survey 2017: Socio-economic Report. Nay Pyi Taw and Yangon, Myanmar: Ministry of Planning, Finance and Industry, UNDP and World Bank.

Diao, X., N. Aung, W.Y. Lwin, P.P. Zone, K.M. Nyunt, and J. Thurlow. 2020. Assessing the Impacts of COVID 19 on Myanmar's Economy - A Social Accounting Matrix (SAM) Multiplier Approach. Myanmar Strategy Support Program Working Paper 01, Yangon: International Food Policy Research Institute.

IOM (International Organization for Migration). 2020. IOM Myanmar COVID-19 Response Situation Report 2, 23 April 2020. Yangon: IOM Myanmar. https://reliefweb.int/report/myanmar/iom-myanmar-covid-19response-situation-report-2-23-april-2020

MOPF (Ministry of Planning and Finance) and World Bank. 2017. An Analysis of Poverty in Myanmar: (Part 2) Poverty Profile. Nay Pyi Taw: MOPF and World Bank-Myanmar.

MOPFI (Ministry of Planning, Finance and Industry). 2020. Overcoming as One: COVID-19 Economic Relief Plan (CERP). Yangon: MOPFI.

Myanmar Times. 2020, May 7. Myanmar ready to quarantine up to 100,000 returning workers. https://www.mmtimes.com/news/myanmar-ready-quarantine-100000-returning-workers. 


\section{ABOUT THE AUTHOR(S)}

Xinshen Diao is Deputy Director of the Development Strategy and Governance Division (DSGD) of the International Food Policy Research Institute (IFPRI), based in Washington, DC. Kristi Mahrt is a Senior Research Analyst in DSGD of IFPRI, based in Colorado, USA.

\section{ACKNOWLEDGMENTS}

This policy note has been prepared at the request of the Myanmar Agricultural Policy Support Activity (MAPSA) and the United States Agency of International Development (USAID). Funding for this study was provided by the CGIAR Research Program on Policies, Institutions, and Markets and USAID. Comments were elicited from MAPSA team members, USAID, and local and international experts. Industry leaders in Myanmar were remotely interviewed to obtain their insights and concerns about the current risks facing their institutions and their clients. The authors thank all contributors for their time and valuable insights, while taking responsibility for the final content.

INTERNATIONAL FOOD POLICY RESEARCH INSTITUTE

1201 Eye St, NW | Washington, DC 20005 USA T. +1-202-862-5600 | F. +1-202-862-5606 ifpri@cgiar.org www.ifpri.org | www.ifpri.info

\section{IFPRI-MYANMAR}

No. 99-E6 U Aung Kein Lane

Than Lwin Road, Bahan Township

Yangon, Myanmar

IFPRI-Myanmar@cgiar.org

www.myanmar.ifpri.info

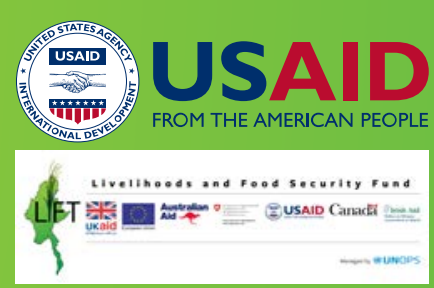

The Myanmar Strategy Support Program (Myanmar SSP) is led by the International Food Policy Research Institute (IFPRI) in partnership with Michigan State University (MSU). Funding support for Myanmar SSP is provided by the CGIAR Research Program on Policies, Institutions, and Markets; the Livelihoods and Food Security Fund (LIFT); and the United States Agency for International Development (USAID). This publication has been prepared as an output of Myanmar SSP. It has not been independently peer reviewed. Any opinions expressed here belong to the author(s) and do not necessarily reflect those of IFPRI, MSU, LIFT, USAID, or CGIAR.

(c) 2020, Copyright remains with the author(s). This publication is licensed for use under a Creative Commons Attribution 4.0 International License (CC BY 4.0). To view this license, visit https://creativecommons.org/licenses/by/4.0. 